Historic, Archive Document

Do not assume content reflects current scientific knowledge, policies, or practices. 


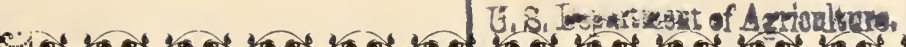

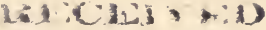

* MAR 131931 *

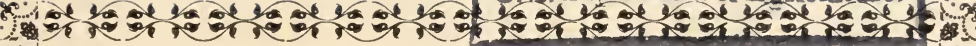

14.

(6)

$2 \%$

(3)

32

(6)

(1).

of

1\%

a)

1\%.

क्रे

1\%

단

1\%

as

1\%

\%

$1 \%$

ots

(1\%)

क्षे

1\%

क्षे

12.

ํㅏㄴ

1\%

\%

s\%

(5)

1\%

(ब)

1\%

of

1\%.

ats

14.

a)

(2)

WHOLESALE

TRADE LIST

FOR THE TRADE ONLY

SPRING 1931

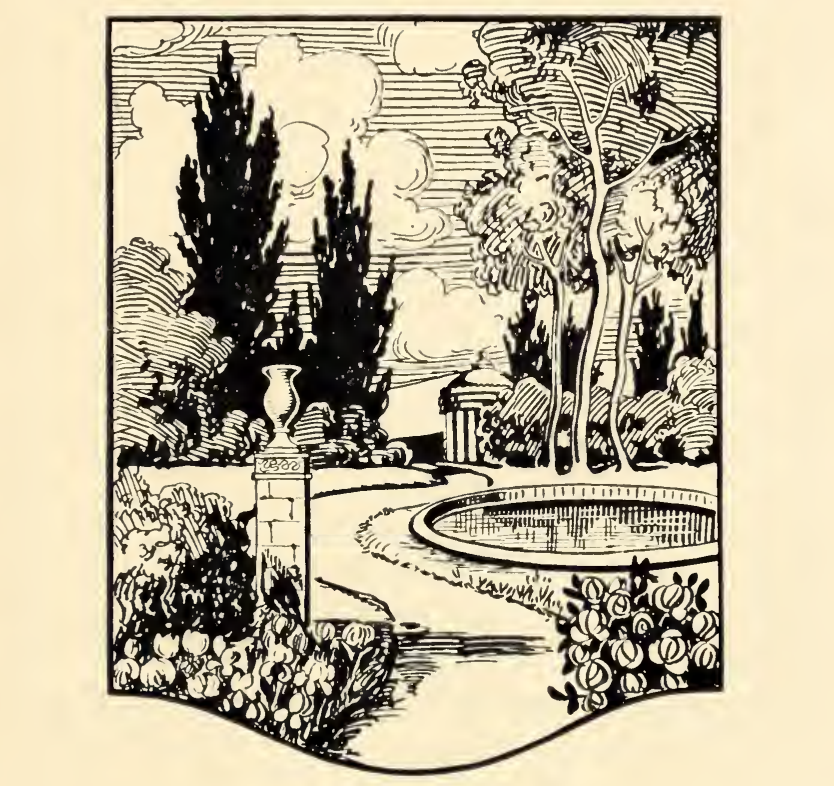

Nursery Stock, Bulbs

3.

(e)

$1 \%$

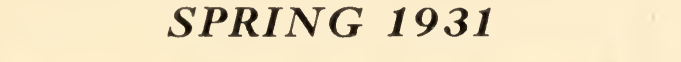

(2)

(4)

1\%

\%5

1\%

\%.

(1)

(t)

(12.

of

(1)

\%

(1)

क्ष

(4)

of

(10)

을

(2)

)

(6)

of

(12)

(5)

(4)

j2

6

\section{Perennials, Etc.}

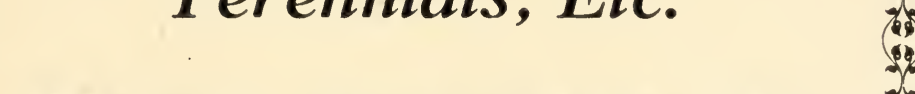

IUUINOIS NUPSERIES, INC. ILLINOIS NURSERIES, INC. HENRY, ILLINOIS

a

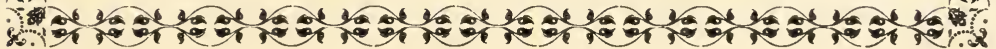




\section{Read Terms of Sale Before Ordering}

We are located on the hard road, Route 29, between Peoria and Chicago, 125 miles from Chicago: Good railroad facilities on C. R. I. and P. R. R. We are pleased to show visitors over our grounds.

\section{TERMS OF SALE}

Shipping. Parties ordering should specify whether to ship by express or freight. In the absence of these instructions, we will forward to the best of our judgment, but in no case will we assume responsibility after consignment to purchaser. All shipments travel at the risk and cost of purchaser.

Terms. Cash or security before shipment of goods except with established firms, when if unknown to us, satisfactory references will be required before goods are shipped. Orders to be sent C. O. D. must be accompanied by one-fourth cash $-2 \%-10$ days. No discount on orders under $\$ 10.00$. All orders F. O. B. Henry, Illinois.

Prices are limited to Spring, 1931, and supercede all prcvious lists and are subject to change without notice. On amounts less than 5 , add 5 cents to 10 rate, over 5 , take 10 rate; on amounts 25 and over, take 100 rate.

Claims. For any cause will receive consideration only when made within ten days after arrival of goods at destination.

Packing. Prices contained herein are net; cost of boxing and baling will be added. No charge is made for loading bulk cars.

Certificate of Inspection will be furnished with each shipment.

\section{Boxing and Packing Charges}

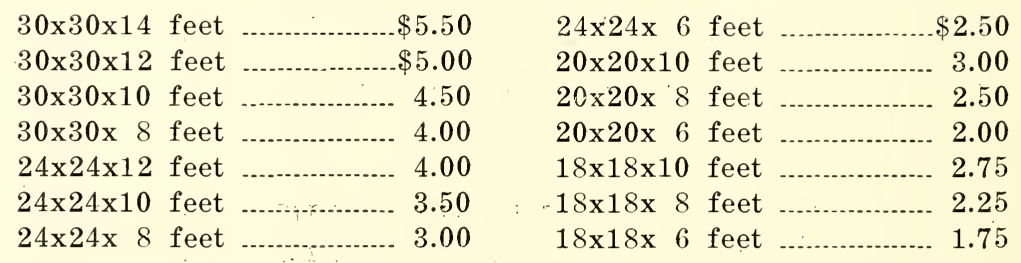




\section{Shade and Ornamental Trees}

\section{ASH (Fraxinus)}

Green (Lanceolata)

Per 10

5 to 6 feet

6 to 8 feet

8 to 10 feet

$1 \frac{1 / 4}{4}$ to $1 \frac{1 / 2}{\text { inch }}$
$\$ \quad 2.20$

3.50

6.00

7.50

Per 100

$\$ 18.00$ 30.00 50.00

BIRCH (Betula)

Cut Leaf Weeping

6 to 8 feet

13.50

8 to 10 feet

18.50

125.00

European White

5 to 6 feet

4.50

6 to 8 feet

6.00

8 to 10 feet

8.50

$1 \frac{1 / 2}{2}$ to $1 \frac{3 / 4}{\text { inch }}$

12.50

American Birch (good for background)

4 to 5 feet (Low Branched)

3.50

5 to 6 feet (Low Branched)

4.50

30.00

40.00

CATALPA BUNGEII

Strong Heads

4 to 5 feet

5.00

6.00

40.00

5 to 6 feet

50.00

CRAB

Bechtel's Double Flowering

18 to 24 inch

2 to 3 feet

3 to 4 feet

2.20

3.00

4.00

4 to 5 feet

6.00

20.00

25.00

35.00

\section{ELM}

American White

5 to 6 feet

6 to 8 feet

2.20

3.50

5.00

8.50

$1 \frac{1}{4}$ to $1 \frac{1}{2}$ inch

13.50

20.00

$13 / 4$ to 2 inch

25.00

Moline EIm

5 to 6 feet

3.50

30.00

6 to 8 feet

6.00

50.00

8 to 10 feet

8.50

75.00

Vase Elm

5 to 6 feet

3.00

25.00

6 to 8 feet

5.50

50.00

8 to 10 feet

7.50

70.00

5 Trees at 10 Rate

25 Trees or more at 100 Rate 


$\begin{aligned} & \text { SHADE AND ORNAMENTAL TREES (Continued) } \\ & \text { LINDEN (Tilia Americana) }\end{aligned}$
American Linden
5 to 6 feet
6 to 8 feet 10

\section{MAPLE}

Norway

5 to 6 feet

6 to 8 feet

8 to 10 feet

9.00

85.00

$1 \frac{1 / 4}{4}$ to $1 \frac{1 / 2}{\text { inch }}$

$\begin{array}{ll}13.50 & 125.00\end{array}$

$1 \frac{1 / 2}{2}$ to $1 \frac{3 / 4}{\text { inch }}$

$16.00 \quad 150.00$

\section{Schwedler}

5 to 6 feet

$1 \frac{1}{4}$ to $1 \frac{1 / 2}{\mathrm{inch}}$

13.50

32.50

Soft or Silver

5 to 6 feet

2.00

3.00

4.00

6.00

9.00

$1 \frac{1}{4}$ to $11 / 2$ inch

$1 \frac{1 / 2}{2}$ to $13 / 4$ inch

9.00

$1 \frac{3}{4}$ to 2 inch

12.50

Sugar Maple

5 to 6 feet

6.50

6 to 8 feet

12.50

8 to 10 feet

16.50

Wiers Cut Leaf

5 to 6 feet

6 to 8 feet

8 to 10 feet

4.00

5.50

35.00

8.50

18.00

25.00

35.00

50.00

85.00

MOUNTAIN ASH (Sorbus)

European

5 to 6 feet

2.80

4.00

25.00

6 to 8 feet

7.50

35.00

8 to 10 feet

MULBERRY (Morus)

\section{Russian}

4 to 5 feet

5 to 6 feet

1.50

6 to 8 feet

2.00

12.00

Tea's Weeping

5 to 6 feet Medium

13.50

16.00

125.00

5 to 6 feet Heavy

5 Trees at 10 Rate

25 Trees or more at 100 Rate 


SHADE AND ORNAMENTAL TREES (Continued)
POPLAR (Populus)
Bolleana
5 to 6 feet $\ldots$ Per 10

PRUNUS (Plum)

Triloba (Double Flowering Plum)

2 to 3 feet

3 to 4 feet

2.80

25.00

3.80

35.00

Newport (Purple Leaf Plum)

3 to 4 feet

$3.00 \quad 25.00$

4 to 5 feet

3.50

30.00

5 to 6 feet

5.00

\section{RE.D BUD}

Cercis Canadensis

$\begin{array}{ll}3 \text { to } 4 \text { feet } & \ldots \\ 4 & \text { to } 5 \text { feet } \\ 5 & \text { to } 6 \text { feet }\end{array}$

SYCAMORE (Platnus)

American Occidentalis

\begin{tabular}{|c|c|}
\hline to 6 feet & 2.50 \\
\hline 6 to 8 feet ............ & 3.50 \\
\hline to 10 feet & 5.00 \\
\hline $1 / 4$ to $1 \frac{1}{2}$ inch & 7.50 \\
\hline $1 / 2$ to $13 / 4$ inch & 10.00 \\
\hline
\end{tabular}

TULIP TREE (Liriodendron)

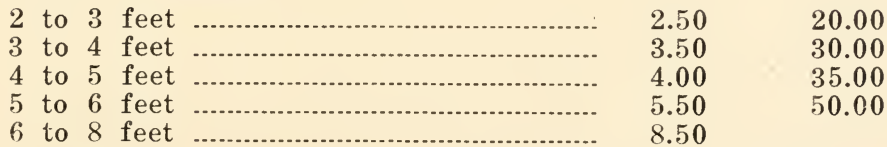

5 Trees at 10 Rate

25 Trees or more at 100 Rate 


\section{SHADE AND ORNAMENTAL TREES (Continued)} WILLOW

$\begin{array}{rrrrr}\text { French Pussy } & & \text { Per } 10 & \text { Per } 100 \\ 2 \text { to } 3 \text { feet } & \ldots \ldots \ldots \ldots \ldots & 1.50 & 10.00 \\ 3 \text { to } 4 & \text { feet }\end{array}$

Niobe (Weeping)

6 to 8 feet

\section{Deciduous Shrubs}

ALMOND

Pink and White Flowering

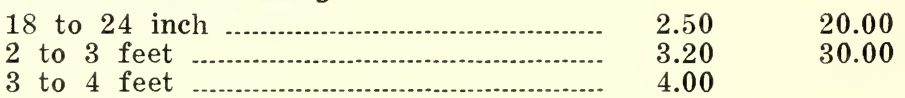

ALTHEA (Bush Form)

Rose of Sharon

2 to 3 feet

3 to 4 feet

$1.80 \quad 15.00$

$2.50 \quad 20.00$

ARALIA (Spinosa)

Devil's Walking Stick

18 to 24 inch

2.00

2 to 3 feet

2.50

15.00

\section{BARBERRY}

\section{Japanese}

12 to 15 inch

15 to 18 inch Heavy

.75

1.00

1.20

1.60

18 to 24 inch Heavy

10.00

24 to 30 inch Heavy

14.00

Red Leaved

9 to 12 inch

12 to 15 inch

2.00

18.00

15 to 18 inch

3.00

25.00

$\begin{array}{ll}3.50 & 30.00\end{array}$

BUDDLEIA (Magnifica)

Butterfly Bush

2 yr. No. 1

\section{CALYCANTHUS}

Sweet Scented Shrub

12 to 18 inch

18 to 24 inch

2.00

15.00

$2.50 \quad 20.00$

CORNUS (Dogwood)

Lutea (Yellow Stemmed)

2 to 3 feet

3 to 4 feet

1.50

12.00

$2.00 \quad 18.00$

5 Plants at 10 Rate

25 Plants or more at 100 Rate 
CORNUS (Continued)

Siberica
DECIDUOUS SHRUBS (Continued)

Per 10

1.00

1.50

2.00

2.50

1.50

1.80

18 to 24 inch

2 to 3 feet

CYDONIA (Japonica)

Japan Quince

12 to 18 inch

18 to 24 inch

2 to 3 feet

DEUTZIA

Gracilis

12 to 18 inch

15 to 18 inch

Pride of Rochester

18 to 24 inch

2 to 3 feet

3 to 4 feet
1.20

1.80

2.50

10.00

15.00

20.00
12.00

15.00
8.00

12.00

15.00

20.00
15.00

1.20

1.50

1.80

8.00

12.00

15.00

ELEAGNUS (Augustifolia)

\section{Russian Olive}

2 to 3 feet

3 to 4 feet

1.50

2.00

2.50

5 to 6 feet

3.20

ELDER (Sambucus)

Golden Leaved

18 to 24 inch

1.20

1.50

10.00

2 to 3 feet

2.00

12.00

15.00

FORSYTHIA

Intermedia (Golden Bell)

2 to 3 feet

3 to 4 feet

1.00

1.20

1.80

12.00

15.00

20.00

HONEYSUCKLE

Bella Albida (White)

3 to 4 feet

2.00

18.00

4 to 5 feet

2.50

22.00

Morrowi (Horizontal Type)

18 to 24 inch

1.20

9.00

2 to 3 feet

1.50

12.00

3 to 4 feet

1.80

15.00

5 Plants at 10 Rate

25 Plants or more at 100 Rate 
HONEYSUCKLE (Cont.)

Tartarian (Upright)

18 to 24 inch

2 to 3 feet

3 to 4 feet
DECIDUOUS SHRUBS (Continued)

Per 10

1.20

1.50

2.00
Per 100

9.00

12.00

18.00

HYDRANGEA

Arb. Grand (Hills of Snow)

12 to 18 inch

18 to 24 inch

1.20

10.00

24 to 30 inch

1.60

14.00

2.00

18.00

Pan. Grand (Fall Blooming)

12 to 18 inch

18 to 24 inch

24 to 30 inch

$\begin{array}{ll}1.20 & 10.00\end{array}$

$1.80 \quad 15.00$

$2.20 \quad 20.00$

\section{Tree Form}

3 to 4 feet

$6.00 \quad 50.00$

Kerria (Japonica)

12 to 18 inch

2.50

LILAC

Common Purple

12 to 18 inch

18 to 24 inch

2 to 3 feet

3 to $3 \frac{1}{2}$ feet

1.00

$1.20 \quad 10.00$

1.50

2.00

12.00

\section{Common White}

12 to 18 inch

1.50

12.00

18 to 24 inch

1.80

15.00

2 to 3 feet

2.50

\section{Persian Purple}

18 to 24 inch

1.20

1.80

10.00

2 to 3 feet

3 to 4 feet

2.20

15.00

20.00

\section{PHILADELPHUS (Syringa)}

Coronarius (Sweet Mock Orange)

18 to 24 inch

2 to 3 feet

$1.00 \quad 8.00$
1.50

$1.50 \quad 10.00$

3 to 4 feet

$\begin{array}{ll}1.80 & 15.00\end{array}$

\section{Grandiflora (Big Mock Orange)}

18 to 24 inch

$1.00 \quad 8.00$

2 to 3 feet

3 to 4 feet

1.50

15.00

\section{Lemoine}

18 to 24 inch

$1.20 \quad 10.00$

2 to 3 feet

$1.80 \quad 15.00$

Virginal (Semi-Double)

18 to 24 inch

$2.20 \quad 18.00$

2 to 3 feet

2.50

22.00

5 Plants at 10 Rate

25 Plants or more at 100 Rate 


\section{DECIDUOUS SHRUES (Continusd)}

\section{PRUNUS (Triloba)}

Double Flowering Plum

2 to 3 feet

Per 10

Per 100

3 to 4 feet

2.80

3.80

25.00

RHODOTYPUS (Kerrioides)

\section{White Kerria}

18 to 24 inch

1.50

2.00

2 to 3 feet

2.50

12.00

3 to $3 \frac{1}{2}$ feet

15.00

20.00

ROSE ACACIA

Pink Moss Locust

18 to 24 inch

2 to 3 feet

1.80

2.20

3 to 4 feet

2.75

15.00

20.00

SNOWBALL (See Viburnum)

SNOWBERRY (Symphoricarpus)

Racomosus (White)

18 to 24 inch ........................................ 1.00

7.00

2 to 3 feet

10.00

3 to 4 feet

1.20

1.60

14.00

Vulgaris (Indian Currant)

2 to 3 feet

$1.50 \quad 12.00$

SPIREA

Anthony Waterer

12 to 15 inch

1.40

1.60

12.00

15 to 18 inch

18 to 24 inch

2.00

18.00

Billardi

18 to 24 inch

2 to 3 feet

3 to $3 \frac{1}{2}$ feet

$1.20 \quad 10.00$

$1.60 \quad 14.00$

Frobelli (Rose Pink)

15 to 18 inch

18 to 24 inch

2.00

24 to 30 inch

1.00

1.20

8.00

Opulifolia Aurea (Golden Ninebark)

18 to 24 inch

2 to 3 feet

3 to 4 feet

1.00

1.50

10.00

$1.50 \quad 12.00$

Opulifolia Nana (Dwarf Ninebark)

18 to 24 inch

2 to 3 feet

3 to 4 feet

1.80

8.00

12.00

15.00

Thumbergi

2 to 3 feet

3 to 4 feet

1.50

12.00

1.60

14.00

2.00

18.00

2.00

15.00

2.50

20.00

5 Plants at 10 Rate

25 Plants or more at 100 Rate 
SPIREA (Continued)

DECIDUOUS SHRUBS (Continued)

Van Houttei

Per 10

Per 100

18 to 24 inch

1.00

7.50

2 to 3 feet

1.20

10.00

3 to 4 feet

1.50

4 feet Heavy

2.00

12.00

4 to 5 feet

2.50

15.00

20.00

SUMAC (Rhus)

Aramatica (Fragrant)

18 to 24 inch

2.80

25.00

2 to 3 feet

3.20

30.00

Cut Leaf (Typhina Laciniata)

2 to 3 feet

1.60

14.00

3 to 4 feet

2.20

20.00

TAMARIX

Amurense (Silver Green Foliage)

18 to 24 inch

1.00

8.00

2 to 3 feet

1.50

12.00

3 to 4 feet

2.00

15.00

Hispida

18 to 24 inch

1.80

15.00

2 to 3 feet

2.20

20.00

\section{VIBURNUM}

Dentatum (Arrow Wood)

18 to 24 inch

1.50

12.00

2 to 3 feet

2.00

15.00

Opulus (H. B. Cranberry)

12 to 18 inch

$1.20 \quad 10.00$

18 to 24 inch

1.50

12.00

2 to 3 feet

2.00

16.00

Opulis Sterilis (Snowball)

18 to 24 inch

1.80

15.00

2 to 3 feet

2.50

WEIGELIA (Diervilla)

Eva Rathke

18 to 24 inch

2.00

16.00

2 to 3 feet

2.50

20.00

Rosea

18 to 24 inch

1.50

12.00

2 to 3 feet

3 to 4 feet

1.80

14.00

2.20

20.00

\section{WILLOW (Salix)}

French Pussy

2 to 3 feet

3 to 4 feet

4 to 5 feet

1.50

10.00

2.00

15.00

2.50

20.00

5 Plants at 10 Rate

25 Plants or more at 100 Rate 


\section{Privet}

AMOOR RIVER NORTH

Per 100

Per 1000

12 to 15 inch Heavy Branched

15 to 18 inch Heavy Branched

18 to 24 inch Heavy Branched

$\$ \quad 3.00$

$\$ 25.00$

2 to 3 feet Heavy Branched.

4.00

5.00

35.00

45.00

6.00

55.00

IBOTA PRIVET

Per 10 Per 100

18 to 24 inch

$\$ \begin{array}{r}1.00 \\ 1.20\end{array}$

$\$ 6.00$

2 to 3 feet

1.50

8.00

3 to $3 \frac{1}{2}$ feet

10.00

REGAL'S PRIVET (True Type)

15 to 18 inch

1.00

8.00

18 to 24 inch

1.50

12.00

\section{Climbing Vines}

\section{AMPELOPSIS}

Englemanni (Engleman's Ivy)

3 year No. 1

Per 10

Per 100

2 year No. 1

1.50

1.20

12.00

2 year Medium

1.00

8.00

Veitchii (Boston Ivy)

3 year Strong

3.00

6.00

2 year No. 1

2.00

25.00

2 year Medium

1.80

\section{BITTERSWEET (Celastrus)}

American (Scandens)

3 year Heavy

2.50

20.00

2 year No. 1

1.80

15.00

2 year Medium

1.20

10.00

\section{CLEMATIS}

Paniculata

2 year No. 1

2.00

15.00

Large Flowering Hybrids

Henryii, Pure White

Jackmanni, Rich Purple

4.50

4.50

42.00

Mme. Ed. Audre, Red

$4.50 \quad 42.00$

HONEYSUCKLE

Hall's Japan

2 year No. 1

WISTERIA (Purple and White)

3 year No. 1

2.50

22.00

2 year No. 1

2.00

18.00

5 Plants at 10 Rate

25 Plants or more at 100 Rate 


\section{Evergreens}

ARBORVITAE

Arrerican

$\begin{array}{rr}\text { Per } 10 & \text { Per } 100 \\ 3.50 & 30.00 \\ 5.00 & 40.00 \\ 8.50 & 75.00 \\ 15.00 & 140.00 \\ 25.00 & \end{array}$

\section{Globe (Woodward's)}

10 to 12 inch B. \& B.

4.00

35.00

$5.00 \quad 45.00$

12 to 15 inch B. \& B.

10.00

90.00

15 to 18 inch B. \& B.

15.00

20.00

140.00

24 to 30 inch B. \& B.

190.00

\section{Pyramid}

10 to 12 inch B. \& B.

$4.00 \quad 35.00$

12 to 18 inch B. \& B.

$\begin{array}{ll}4.000 & 50.00\end{array}$

18 to 24 inch B. \& B.

2 to $2^{1 / 2}$ feet B. \& B.

$2^{1 / 2}$ to 3 feet B. \& B.

3 to $3 \frac{1}{2}$ feet $B$. \& B.

$3^{1 / 2}$ to 4 feet B. \& B.

$\begin{array}{ll}7.50 & 70.00\end{array}$

$10.00 \quad 90.00$

$15.00 \quad 140.00$

$20.00 \quad 190.00$

\section{JUNIPER}

\section{Pfitzeriana}

15 to 18 inch B. \& B.

10.00

90.00

18 to 24 inch B. \& B.

2 to $2 \frac{1}{2}$ feet B. \& B.

17.50

160.00

$2^{1 / 2}$ to 3 feet B. \& B.

25.00

30.00

3 to $3 \frac{1}{2}$ feet B. \& B.

$3^{1 / 2}$ to 4 feet B. \& B.

35.00

40.00

\section{Irish Juniper}

2 to $2 \frac{1}{2}$ feet B. \& B.

10.00

90.00

$2^{1 / 2}$ to 3 feet B. \& B.

3 to $3 \frac{1}{2}$ feet B. \& B.

12.50

115.00

15.00

140.00

$3^{1 / 2}$ to 4 feet B. \& B.

20.00

\section{Swedish Juniper}

18 to 24 inch B. \& B.

2 to $2 \frac{1}{2}$ feet B. \& B.

10.00

12.50

115.00

$15.00 \quad 140.00$

$2^{1 / 2}$ to 3 feet B. \& B.

190.00

3 to $3 \frac{1}{2}$ feet B. \& B.

20.00

25.00

\section{Virginiana (Red Cedar)}

18 to 24 inch B. \& B. 


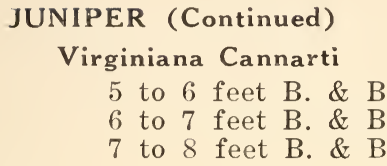

EVERGREENS (Continued)

Per 10 Per 100

65.00

75.00

85.00

FIR

Balsam Fir (Abies Balsamea)

2 to 3 feet B. \& B.

25.00

225.00

3 to 4 feet B. \& B.

32.50

Douglas Fir (Abies Douglassi)

18 to 24 inch B. \& B.

10.00

90.00

2 to 3 feet B. \& B.

17.50

165.00

3 to 4 feet B. \& B.

27.50

\section{PINUS}

Mugho Pine

10 to 12 inch B. \& B

8.50

75.00

$12 \times 12$ inch B. \& B

10.00

90.00

$15 \times 15$ inch B. \& B.

12.50

$18 \times 18$ inch B. \& B

115.00

$21 \times 21$ inch B. \& B

15.00

$24 \times 24$ inch B. \& B.

17.50

22.50

\section{Scotch Pine}

12 to 18 inch B. \& B.

18 to 24 inch B. \& B.

2 to $2 \frac{1}{2}$ feet B. \& B

5.00
7.50

40.00

10.00

$2^{1 / 2}$ to 3 feet B. \& B.

15.00

White Pine

3 to 4 feet B. \& B.

20.00

4 to 5 feet B. \& B

25.00

5 to 6 feet B. \& B

30.00

\section{SPRUCE}

\section{Colorado Blue}

12 to 18 inch B. \& B.

18 to 24 inch B. \& B.

35.00

\section{Colorado Green}

12 to 18 inch B. \& B. .................................. 100

18 to 24 inch B. \& B.

15.00

\section{Black Hill}

12 to 18 inch B. \& B.

18 to 24 inch B. \& B.

10.00

2 to $2 \frac{1 / 2}{2}$ feet B. \& B.

15.00

\section{Norway}

12 to 18 inch B. \& B.

18 to 24 inch B. \& B.

4.00

35.00

2 to $2 \frac{1}{2}$ feet B. \& B.

$2^{1 / 2}$ to 3 feet $B$. \& $B$.

6.00

50.00

3 to 4 feet B. \& B.

7.50

65.00

4 to 5 feet B. \& B.

12.50

17.50

22.50

5 Trees at 10 Rate

25 Trees or more at 100 Rate 


\section{SPRUCE (Continued)}

White Spruce

12 to 18 inch B. \& B

18 to 24 inch B. \& B

2 to $2^{1 / 2}$ feet B. \& B.
EVERGREENS (Continued)

Per 10

5.00

7.00

9.00
Per 100

40.00

60.00

80.00

\section{Roses}

HYBRID TEA ROSES

Two Year No. 1

Columbia

Etolie de France.

Gruss an Teplitz.

Kaiserin A. Victoria.

Lady Hillingdon

Los Angeles

Radiance

Red Radiance

Souv. de'Claudius Pernet.
Bright Pink

Dark Crimson

Velvety Red

Best White

Apricot Yellow ......

Coral Pink

Rose Pink

Bright Rosy Red....

Pure Yellow
Per 10

3.20

3.20

3.20

3.20

3.20

3.50

3.20

3.20

3.70
Per 100

$\$ 30.00$

30.00

30.00

30.00

30.00

32.00

30.00

30.00

35.00

\section{CLIMBING ROSES}

Two Year No. 1

Climbing Ámer. Beauty........Carmine Red

Crimson Rambler

Dorothy Perkins

Deep Crimson

3.00

2.50

2.20

3.00

Shell Pink

Dark Rose

2.20

Creamy Yellow ......

Excelsa

Gardenia

Vivid Scarlet

3.00

25.00

20.00

18.00

28.00

18.00

20.00

Paul's Scarlet

\section{RUGOSA ROSES}

\section{Two Year No. 1}

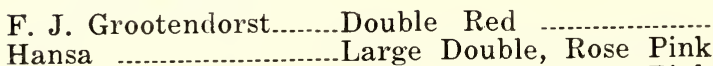
Hansa
Sarah Van Fleet........... Double, Wild, Rose Pink

\section{BABY RAMBLER ROSES}

Baby Crimson Rambler Dark Crimson

3.50

\section{Fruit Trees}

APPLE AND CRAB

11-16 and up, Selected $\$ \quad 3.00$

9-16 and up, Selected

Delicious

Duchess of Old

Early Harvest

N. W. Greening Jonathan

5 Trees at 10 Rate
Maiden Blush McIntosh Red Snow Fameuse Stayman Winesap Tolman Sweet
Wealthy

Yellow Transparent

Hyslop Crab

Siberian Crab

Whitney Crab 


\section{FRUIT TREES (Continued)}

CHERRY

$\begin{array}{rr}\text { Per } 10 & \text { Per } 100 \\ 4.00 & \\ 3.50 & 32.00 \\ 3.00 & 25.00 \\ 4.00 & \\ 3.50 & 32.00 \\ 3.00 & 25.00 \\ 4.50 & 40.00\end{array}$

PEAR

Two year, 7-8 and up

Two year, 11-16 and up

4.00

3.50

3.00

30.00

Two year, 9-16 and up

25.00

Bartlett Clapps Favorite

Duchess Flemish Beauty

Keiffer

Seckel

\section{PEACH}

One year, 11-16 and up

2.50

Champion

Elberta

Crawford

J. H. Hale

Greensboro

Early White

\section{PLUM}

One inch and up

$\begin{array}{ll}4.00 & 35.00 \\ 3.00 & 25.00 \\ 2.50 & 20.00\end{array}$

11-16 and up

$2.50 \quad 20.00$

9-16 and up

Abundance

Bradshaw

Imperial Gage

Burbank

German Prune

Shropshire Damson

\section{APRICOT}

11-16 and up

4.50

9-16 and up

3.50

\section{Small Fruits}

CURRANTS

Per 10

Per 100

Cherry (Large Red), Two year No. 1

1.00

8.00

Fay's Prolific, Two year No. 1

1.20

1.00

10.00

London Market, Two year No. 1

8.00

White Grape, Two year No. 1

1.20

10.00

\section{GOOSEBERRIES}

Carrie, Two year No. 1

Downing, Two year No. 1

GRAPES

Agawam, Light Red, Two year No. 1

1.20

9.00

Brighton, Dark Red, Two year No.

1.50

10.00

Concord, Black, Two year No. 1

.75

6.00

Moores Diamond, White, Two year No. 1...-

1.20

9.00

Moore's Early, Black, Two year No. 1.......

1.20

10.00

Niagara, White, Two year No.

1.20

9.00

\section{RHUBARB (Linnaeus)}

Two year, Extra Heavy

Two year No. 1 


\section{GARDEN ROOTS AND SMALL FRUITS}

\begin{tabular}{|c|c|c|}
\hline ASPARAGUS (Washington Rust Proof) & 100 & Per 1000 \\
\hline Two year, Selected, Extra Heavy ................\$ & 2.00 & $\$ 15.00$ \\
\hline Two year No. 1 & 1.50 & 12.00 \\
\hline RASPBERRIES & & \\
\hline Cumberland, Best Black & 2.20 & 18.00 \\
\hline Columbian, Large Purple & 3.50 & 30.00 \\
\hline 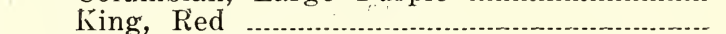 & 2.50 & 20.00 \\
\hline Latham, Best New Red & 3.50 & 30.00 \\
\hline BLACKBERRIES & & \\
\hline Early Harvest ..............Root Cuttings .. & 3.00 & 25.00 \\
\hline 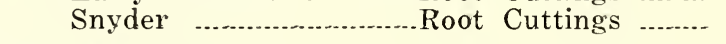 & 3.50 & 30.00 \\
\hline 3ERRIES & & \\
\hline Senator Dunlap & .75 & 6.00 \\
\hline Gibson & .75 & 6.00 \\
\hline Premier & .75 & 6.00 \\
\hline Mastádon & 2.00 & 15.00 \\
\hline
\end{tabular}

\section{Hardy Perennials}

AQUILEGIA (Columbine)

Per I0 Per 100

Mrs. Scott Elliot Hybrids

$\begin{array}{llll}\$ & 1.20 & \$ 10.00\end{array}$

BLEEDING HEART

$3.00 \quad 25.00$

CAMPANULA (Medium)

Canterbury Bells

COREOPSIS (Lanceolata)

Golden Yellow

$1.00 \quad 8.00$

DAISY

Shasta Alaska ............................................. $1.00 \quad 7.00$

DELFHINIUM

Belladonna

Light Blue

1.00

Bellamosa

Dark Blue

1.00

1.00

8.00

Woodacre Hybrids

Assorted Colors

8.00

\section{DIANTHUS}

Hardy Pinks

1.00

8.00

\section{GYPSOPHILA (Baby Breath)}

Paniculata

$1.00 \quad 8.00$

FUNKIA (Plantain Lily)

Blue

\section{HEMEROCALLIS (Day Lily)}

Lemon Lily ................... Light Yellow

Orange Lily

Deep Yellow

1.20

10.00

Thumbergi Japanese Day Lily..

1.20

1.20

10.00

\section{Plants or more at 10 Rate}

25 Plants or more at 100 Rate 


\section{HARDY PERENNIALS (Continued)}

IRIS

Per 10 Per 100

German Iris, Assorted Varieties

$.60 \quad 4.00$

Caprice, Rosy Red

Lohengrin, Silver Mauve

Monsignor, Violet Blue

Mad. Chereau, White, Blue Edge

Perfection. Two Shades Blue

Parc. de Mille, Purple

Queen of May, Lav. Pink

Sherwin Wright, Pure Yellow

\section{SIBERIAN IRIS}

Blue

1.00

8.06

PAPAVER (Orientale)

Oriental Poppy

1.50

12.00

\section{PHLOX (Paniculata)}

Our Phlox have all been potted in 3 -inch pots and are well established and insures you an almost perfect stand.

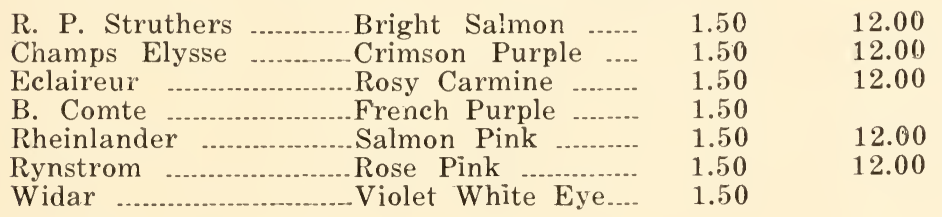

PYRETHRUM (Roseum)

Painted Daisy ......................................... 1.00

PLATYCODON (Ballon Flower)

Blue and White Mixed ............................... $1.00 \quad 8.00$

STATICE (Latifolia)

Light Blue, Three Year ............................. $1.50 \quad 12.00$

YUCCA (Filamentosa)

Adam's Needle, Three Year ..................... $1.00 \quad 8.00$

\section{Gladioli Bulbs}

Choice No. I Bulbs, $11 / 2$ inch and up Per 100

Alice Tiplady

E. J. Shaylor

Gaiety

Glendale

Halley

Odin

Peace

Pella

Willbrinck

Choice Mixed

5 Plants or more at 10 Rate
Orange

Deep Pink

Bright Pink

Purplish Red

Soft Red

Salmon Red

Late White

Rose Pink

Soft Pink
$\$ \quad 2.00$

2.00

2.00

2.00

1.50

2.00

2.00

2.00

1.50

1.20
Per 1000

$\$ 15.00$

15.00

15.00

15.00

12.00

15.00

15.00

15.00

12.00

10.00 


\section{Peonies}

Strong 3 to 5 eye Divisions

Per 10 Per 100

Alexandriana .........................Large Pink

Couronne d'Or

Late White

2.50

1.80

Duchess de Nemours .............Pure White

1.80

Delicatissima

Edulis Superba

Good Pink

Festive Maxima

Dark Pink

2.00

1.80

2.00

Best Red

Mrs. Douglas

Large Pink

3.20

2.00

$\$ 20.00$

Octavie de May

Shell Pink

Louis Van Houtt

Dark Red

2.50

2.00

Late Rose

1.80

15.00

15.00

18.00

15.00

18.00

28.00

18.00

20.00

Rose Fragrance

PEONIES TO COLOR

Double Pink

1.50

1.80

12.00

Double Red

1.50

15.00

Double White

25 Plants or more at 100 Rate

5 Plants or more at 10 Rate

12.00 

